\title{
Generation of hydrogen peroxide and failure of antioxidative responses in pancreatic islets of male C57BL/6 mice are associated with diabetes induced by multiple low doses of streptozotocin
}

\author{
N. T. E. Friesen ${ }^{1}$ A. S. Büchau ${ }^{1}$ P. Schott-Ohly ${ }^{1}$ A. Lgssiar $^{1}$ • H. Gleichmann ${ }^{1}$ \\ ${ }^{1}$ German Diabetes Center, German Diabetes Research Institute, Heinrich-Heine-University, Düsseldorf, Germany
}

\begin{abstract}
Aims/hypothesis. We studied the impact of the reactive oxygen species hydrogen peroxide $\left(\mathrm{H}_{2} \mathrm{O}_{2}\right)$ and antioxidative enzymes on the pathogenesis of diabetes induced by multiple low doses of streptozotocin (MLDSTZ).

Methods. We isolated the islets of C57BL/6 mice. For ex vivo analyses, mice had been injected with MLDSTZ. For in vitro analyses, islets were incubated with different concentrations of STZ, with either of the two moieties of STZ, methylnitrosourea and D-glucose, with $\mathrm{H}_{2} \mathrm{O}_{2}$ or with alloxan. Levels of $\mathrm{H}_{2} \mathrm{O}_{2}$ generation were measured by the scopoletin method. We assessed mRNA expression of $\mathrm{Cu} / \mathrm{Zn}$ and $\mathrm{Mn}$ superoxide dismutase, catalase, and glutathione peroxidase (GPX) by semiquantitative polymerase chain reaction. GPX activity was measured spectrophotometrically. In vitro, beta cell function was assayed by measuring basal and D-glucose-stimulated release of immunoreactive insulin using an ELISA kit.
\end{abstract}

Received: 9 October 2003 / Accepted: 21 November 2003

Published online: 1 April 2004

(C) Springer-Verlag 2004

H. Gleichmann (

German Diabetes Center, German Diabetes Research Institute,

Heinrich-Heine-University, Auf'm Hennekamp 65,

40225 Düsseldorf, Germany

E-mail: gleich@ddfi.uni-duesseldorf.de

Tel.: +49-211-751874, Fax: +49-211-3382-603

Abbreviations: GPX, glutathione peroxidase $\cdot \mathrm{H}_{2} \mathrm{O}_{2}$, hydrogen peroxide $\cdot$ HD-STZ, high-dose streptozotocin $\cdot$ HRP, horse radish peroxidase $\cdot$ IRI, immunoreactive insulin $\cdot$ MLD-STZ, multiple low doses of streptozotocin $\cdot \mathrm{NF}-\kappa \mathrm{B}$, nuclear factor kappa $\mathrm{B} \cdot \mathrm{O}_{2}^{--}$, superoxide radical $\cdot \mathrm{OH}$, hydroxyl radicals · ROS, reactive oxygen species $\cdot$ SOD, superoxide dismutase
Results. Ex vivo, MLD-STZ significantly increased $\mathrm{H}_{2} \mathrm{O}_{2}$ generation in male but not in female mice. It also increased GPX activity and mRNA expression of catalase, $\mathrm{Cu} / \mathrm{Zn}$ and $\mathrm{Mn}$ superoxide dismutase, and GPX in female but not in male mice. In vitro, STZ significantly stimulated $\mathrm{H}_{2} \mathrm{O}_{2}$ generation in islets of male mice only. In male islets, alloxan increased $\mathrm{H}_{2} \mathrm{O}_{2}$ generation at a highly toxic concentration, but D-glucose and methylnitrosourea did not. Both STZ and $\mathrm{H}_{2} \mathrm{O}_{2}$ dose-dependently inhibited the release of immunoreactive insulin after a $\mathrm{D}$-glucose challenge.

Conclusions/interpretation. The results indicate that $\mathrm{H}_{2} \mathrm{O}_{2}$ participates in the pathogenesis of MLD-STZ diabetes in male C57BL/6 mice, which do not up-regulate antioxidative enzymes in islets. Conversely, female mice are protected, probably due to an increment of several enzymes with the potential to detoxify $\mathrm{H}_{2} \mathrm{O}_{2}$.

Keywords Antioxidative enzymes $\cdot$ Hydrogen peroxide $\cdot$ MLD-STZ diabetes

\section{Introduction}

Type 1 diabetes is considered to be the result of a multifactorial process also involving T-cell-mediated inflammatory immune reactions $[1,2]$. Reactive oxygen species (ROS) and nitrogen monoxide are implicated as mediators of beta cell destruction in animal models of diabetes [2, 3, 4]. There is substantial indirect evidence for the participation of ROS in the pathogenesis of diabetes, in particular the fact that the overexpression of antioxidants targeted at beta cells protects against the disease. Thus, overexpression of the super-

N. T. E. Friesen and A. S. Büchau contributed equally to this work, it being part of their doctoral theses 
oxide radical $\left(\mathrm{O}_{2}^{--}\right)$-scavenging enzyme, $\mathrm{Cu} / \mathrm{Zn}$ superoxide dismutase (SOD), protects against alloxaninduced diabetes [5]; the hydrogen peroxide $\left(\mathrm{H}_{2} \mathrm{O}_{2}\right)-$ converting enzyme, catalase, delays hyperglycaemia induced with one single high dose of streptozotocin (HD-STZ) [6]; the redox-active protein, thioredoxin, markedly reduces the cumulative incidence of spontaneous diabetes in non-obese diabetic mice and HDSTZ-induced diabetes [7]; and the ROS-scavenging protein, metallothionein, reduces HD-STZ-induced hyperglycaemia [8]. Lenzen et al. [9, 10, 11] have reported that overexpression of antioxidative enzymes in insulin-producing RINm5F cells also protects against oxidative stress. Their results clearly indicate that beta cells can counteract ROS by acquiring sufficient defence mechanisms, but direct measurements of ROS levels were not taken. Nevertheless, since insulin-producing cells appear particularly vulnerable to oxidative stress, probably due to their low levels of ROS-scavenging enzymes [12], their targeted overexpression may confer resistance.

In the putative Type 1 diabetes model induced with multiple low doses of streptozotocin (MLD-STZ) in male mice of susceptible strains, T-cell-dependent inflammatory immune reactions [13] are required subsequent to damage of the beta cell GLUT2 [14] for the disease to develop. Local production of pro-inflammatory cytokines [15] and activation of the transcription factors nuclear factor kappa $\mathrm{B}(\mathrm{NF}-\kappa \mathrm{B})$ and activator protein 1 [16] in isolated islets are associated with MLD-STZ diabetes. Pro-inflammatory cytokines may produce ROS [17], which activate the sensitive NF- $\kappa \mathrm{B}[18]$ involved in gene activation of cytokines. These interactions may sustain chronic inflammatory processes. Hence, MLD-STZ diabetogenesis appears to involve more complex mechanisms than the capacity of STZ to alkylate DNA as reported for in vitro systems $[19,20]$. Since we have already reported generation of ROS in pancreatic islets after incubation with STZ in vitro [21], we aimed in this study to elucidate the impact of local $\mathrm{H}_{2} \mathrm{O}_{2}$ generation and antioxidant responses in islets in MLD-STZ diabetogenesis.

\section{Materials and methods}

Animals. We obtained 5 to 6-week-old C57BL/6 mice of both sexes from Harlan Winkelmann (Borchen, Germany). Mice were 7 to 8 weeks old at the beginning of the experiments. They were kept under specific pathogen-free conditions and were given a rodent diet (ssniff diet for mice, Soest, Germany) and free access to drinking water. The animal studies were conducted in accordance with the "Principles of laboratory animal care" as well as with the current version of the German law on the protection of animals.

Materials. Collagenase (0.42 U/mg) and Tris were supplied by Serva (Heidelberg, Germany). D-glucose, catalase, scopoletin (7-hydroxy-6-methoxy-2H-1-benzopyrane-2-on, 6-methoxyumbelliferone), alloxan, methylnitrosourea, horse-radish per- oxidase (HRP), glutathione peroxidase (GPX), EDTA, RPMI 1640 culture medium and $\mathrm{H}_{2} \mathrm{O}_{2}$ were purchased from Sigma (Deisenhofen, Germany). Penicillin-streptomycin was purchased from Gibco (Eggenstein, Germany), lymphocyte separation medium from Biochrom (Berlin, Germany), and FCS from Invitrogen (Karlsruhe, Germany). Reagents for KRB and t-butylhydroperoxide were supplied by Merck (Darmstadt, Germany). NADPH, glutathione, glutathione reductase and STZ were purchased from Roche Diagnostics (Mannheim, Germany), protein assay dye reagent was obtained from BioRad (Munich, Germany), and the mouse insulin ELISA was purchased from Mercodia (Uppsala, Sweden).

Treatment of mice. To induce diabetes, mice were injected i.p. with MLD-STZ $(5 \times 40 \mathrm{mg} \mathrm{STZ/kg}$ body weight on 5 consecutive days) [22]. STZ was dissolved in $0.1 \mathrm{~mol} / \mathrm{l}$ sodium citrate buffer $(\mathrm{pH} 4.0)$ at a concentration of $0.4 \%$ and injected within 5 min. Solvent-injected mice and MLD-STZ-injected female mice served as controls. Untreated mice were not included as controls, since previous studies have demonstrated that the results correspond to those obtained in solvent-treated mice [23]. By using solvent-injected control groups, non-specific effects due to i.p. injections are taken into account. Pancreatic islets were isolated from solvent-injected mice on day 3 after the final injection and from MLD-STZ-injected mice on day 1 and/or day 3 after the final injection. These time points were chosen because islets isolated from comparable treated groups did not differ significantly in number [24] and in total protein levels ( $\mu \mathrm{g} /$ islet) [14]. An essential contribution of contaminating leukocytes as an $\mathrm{H}_{2} \mathrm{O}_{2}$ donor is excluded by using islets isolated on day 1 and/or day 3 after the final STZ injection. Any immune responses are only initiated, and mononuclear cell infiltrates, if at all present, are minimal [25].

Isolation and treatment of islets. Pancreatic islets were isolated by collagenase digestion as described previously [24], and cultured free-floating in RPMI 1640 medium containing $5.6 \mathrm{mmol} / \mathrm{l} \mathrm{D}$-glucose, $10 \% \mathrm{FCS}, 100 \mathrm{U} / \mathrm{ml}$ penicillin and $0.1 \mathrm{mg} / \mathrm{ml}$ streptomycin in an atmosphere of $95 \%$ air and $5 \%$ $\mathrm{CO}_{2}$ at $37{ }^{\circ} \mathrm{C}$ for $2 \mathrm{~h}$. To analyse $\mathrm{H}_{2} \mathrm{O}_{2}$ generation induced by MLD-STZ in vivo or STZ in vitro, groups of 150 islets were kept in $2700 \mu \mathrm{KRB}$ without BSA at $37^{\circ} \mathrm{C}$. To compare STZmediated $\mathrm{H}_{2} \mathrm{O}_{2}$ levels with the potent $\mathrm{H}_{2} \mathrm{O}_{2}$-generating compound, alloxan, islets were incubated with the latter diabetogen using concentrations equimolar to STZ. In vitro, islets were incubated with $1,3,6$ or $10 \mathrm{mmol} / 1 \mathrm{STZ}$ or with $0.5,1,2,4,6$ or $10 \mathrm{mmol} / \mathrm{l}$ alloxan at $37{ }^{\circ} \mathrm{C}$ for $30 \mathrm{~min}$. STZ was dissolved in sodium citrate; alloxan was dissolved in saline $(0.9 \%)$. Islets incubated with only the solvent served as controls. To investigate which of the two moieties of STZ induces $\mathrm{H}_{2} \mathrm{O}_{2}$ generation, islets were incubated with 1,3 or $6 \mathrm{mmol} / \mathrm{l}$ methylnitrosourea or $1,3,6,10$ or $20 \mathrm{mmol} / 1 \mathrm{D}$-glucose at $37{ }^{\circ} \mathrm{C}$ for $30 \mathrm{~min}$. In these experiments, both substances were dissolved in sodium citrate buffer $(\mathrm{pH} \mathrm{4.0)}$. Islets treated with only the solvent served as controls. At the end of the incubation period, the supernatants were immediately removed and used for $\mathrm{H}_{2} \mathrm{O}_{2}$ analysis.

To test ex vivo effects of MLD-STZ or in vitro effects of STZ on GPX activity, groups of islets of 4 donor mice were isolated and pooled. For GPX activity measurements, 300 islets of the different experiments were homogenised. For ex vivo measurements, islets of MLD-STZ-injected mice of both sexes were isolated on day 1 and/or day 3 after the final injection. Islets of solvent-injected mice served as controls. In vitro, islet cultures were incubated with $6 \mathrm{mmol} / \mathrm{l} \mathrm{STZ}$ at $37{ }^{\circ} \mathrm{C}$ for 30 min; solvent-treated cultures served as controls. To analyse the effects of $\mathrm{H}_{2} \mathrm{O}_{2}$ and STZ on beta cell function in vitro, islet 
cultures were set up for basal and glucose-stimulated release of immunoreactive insulin (IRI) as previously described [26] with slight modifications. Triplicates of 10 islets were suspended in $230 \mu \mathrm{KRB}$ in culture plates, and $20 \mu \mathrm{l}$ of an $\mathrm{H}_{2} \mathrm{O}_{2}$ or STZ solution were added to obtain the required concentrations. Cultures supplemented with $\mathrm{KRB}$, the solvent of $\mathrm{H}_{2} \mathrm{O}_{2}$, or sodium citrate, the solvent of STZ, served as controls. For measuring basal IRI, islets of each culture were transferred into $500 \mu \mathrm{l}$ $\mathrm{KRB}$ and incubated at $37{ }^{\circ} \mathrm{C}$ for $60 \mathrm{~min}$, and the medium was collected for measurement. For measuring stimulated IRI, islets were transferred to another well containing $480 \mu \mathrm{KRB}$ supplemented with a final concentration of $16.7 \mathrm{mmol} / \mathrm{l} \mathrm{D}$-glucose. They were then incubated for $60 \mathrm{~min}$ at $37^{\circ} \mathrm{C}$ before the medium was collected for measurement. All medium samples were kept at $-20{ }^{\circ} \mathrm{C}$ until IRI measurement.

Measuring $\mathrm{H}_{2} \mathrm{O}_{2}$. To investigate whether MLD-STZ-induced $\mathrm{H}_{2} \mathrm{O}_{2}$ generation is associated with diabetes, $\mathrm{H}_{2} \mathrm{O}_{2}$ levels were measured in islets ex vivo of MLD-STZ-injected diabetes-susceptible male mice and diabetes-resistant female mice. $\mathrm{H}_{2} \mathrm{O}_{2}$ levels were measured by the scopoletin method [27, 28]. Briefly, $20 \mu \mathrm{l} \mathrm{HRP}$ and $10 \mu \mathrm{l}$ scopoletin were added to $2700 \mu \mathrm{l}$ of the supernatant of an islet culture. In the presence of HRP, scopoletin is oxidised by $\mathrm{H}_{2} \mathrm{O}_{2}$ and loses its fluorescence capacity, which was continuously measured by excitation $(350 \mathrm{~nm})$ and emission spectra $(460 \mathrm{~nm})$ with a Perkin-Elmer LS-5 Luminescence spectrometer (Beckmann, DU 650, Munich, Germany) for $10 \mathrm{~min}$. To test the effects of antioxidants on STZ-induced $\mathrm{H}_{2} \mathrm{O}_{2}$ generation, $20 \mu \mathrm{l}$ of the $\mathrm{H}_{2} \mathrm{O}_{2}$-metabolising enzyme, catalase $(1000 \mathrm{U} / \mathrm{ml})$ were added to the supernatant immediately after the addition of scopoletin.

GPX assay. To study whether the sex-dependent MLD-STZ effects on $\mathrm{H}_{2} \mathrm{O}_{2}$ generation in islets are inversely correlated with the effects on antioxidative intracellular responses, GPX activities were measured in islets of MLD-STZ-injected mice of both sexes. GPX (Enzyme Commission 1.11.1.9) activity was assayed according to the instructions described by Paglia and Valentine [29] with slight modifications. Briefly, glutathione $(1 \mathrm{mmol} / \mathrm{l})$, NADPH $(0.2 \mathrm{mmol} / \mathrm{l})$ and glutathione reductase $(0.6 \mathrm{U} / \mathrm{ml})$ were dissolved in Tris-HCl/EDTA (50 mmol/l-5 mmol/l, pH 7.6). Tert-butyl hydroperoxide $(0.22 \mathrm{mmol} / \mathrm{l})$ was dissolved in deionised water. Homogenates of 300 islets were sonicated 3 times at $4{ }^{\circ} \mathrm{C}$ for 10 seconds in $1 \mathrm{ml}$ Tris/EDTA buffer (Bandelin Sonoplus HD 60; Merck).

The reaction was started by adding $70 \mu \mathrm{l}$ of the homogenate to $1050 \mu \mathrm{l}$ of the Tris/EDTA buffer. The NADPH oxidation rate was recorded at $340 \mathrm{~nm}$ for $3 \mathrm{~min}$ and the enzyme activity was calculated as nmol NADPH oxidised $\cdot \mathrm{min}^{-1} \cdot \mathrm{mg}$ protein ${ }^{-1}$ using a molar extinction coefficient of $6.22 \times 10^{3} \cdot \mathrm{mol} / \mathrm{l}^{-1} \cdot \mathrm{cm}^{-1}$. To measure total protein, $30 \mu \mathrm{l}$ of the supernatant was used with a Bio-Rad protein assay kit.

$R N A$ preparation and RT-PCR. To analyse whether the effect of MLD-STZ on antioxidative enzymes is systemic or at least preferential for pancreatic islets, the mRNA expression of $\mathrm{Cu} / \mathrm{Zn}$ and Mn SOD, catalase, GPX1 and GPX4 was measured in liver specimens. Total RNA was extracted from pooled islets isolated from groups of 10 mice using the Trizol reagent kit (Life Technologies, Gaitherburg, Md., USA) [30]. The donor mice had been injected with MLD-STZ or its solvent. The RNA preparation was stored at $-80{ }^{\circ} \mathrm{C}$ until use. By using Moloney murine leukaemia virus RT (Gibco), $1 \mu \mathrm{g}$ of total RNA from islets was reversibly transcribed into cDNA, followed by the amplification of target genes by PCR. For the amplification of mouse $\mathrm{Cu} / \mathrm{Zn}$ and $\mathrm{Mn}$ SOD, catalase, GPX1, GPX4 and the housekeeping gene, $\beta$-actin, as an internal con- trol, primer pairs were commercially synthesised by MWGBiotech (Ebersberg, Germany): Cu/Zn SOD 5'-ggacctcattttaatcctc-3', 3'-tacacaggtaacttctagc-5'; Mn SOD 5'-tcaacgccaccgaggagaagta- $3^{\prime}, 3^{\prime}$-tggagtgagtgccggtgtaac-5'; catalase $5^{\prime}$-cgttttacatccaggtcat-3', 3'-gactcttcggattcttgcg-5'; GPX1 5'-gcgaagtgaatggtgagaa- $3^{\prime}, 3^{\prime}$-aacagtggaaaacctatcg-5'; GPX4 5'-cgaattctcagccaaggacat- $3^{\prime}, \quad 3^{\prime}$-ctcacaccaaatgcttaggac-5'; $\beta$-actin 540 , $5^{\prime}$-gtgggccgctctaggcaccaa- $3^{\prime}, \quad 3^{\prime}$-ctcttttagatgtcacgcacgatttc- $5^{\prime}$; $\beta$-actin 795, 5'-aagtacccattgaacatg-3', 3'-gtacaagttaccccatgaa-5'. The RT reaction was amplified using Taq polymerase (Roche Diagnostics). The cycle numbers were chosen to be on the linear (exponential) phase of the amplification of the seven genes: 35 for catalase, $\mathrm{Cu} / \mathrm{Zn}$ SOD, and GPX4; 30 for $\mathrm{Mn}$ SOD and $\beta$-actin 540; 43 for GPX1; and 22 for $\beta$-actin 795. For separation, $10 \mu \mathrm{g}$ of the amplified PCR products were loaded on $1.5 \%$ agarose gels containing ethidium bromide $(0.1 \mu \mathrm{g} / \mathrm{ml})$. The resulting bands were quantified by LumiAnalyst TM (Roche Diagnostics). To eliminate the possibility of genomic DNA contamination during RNA preparation, negative controls were set up for each PCR amplification using purified RNA as a template.

IRI measurement. Samples were analysed for IRI concentrations using an ELISA kit according to the manufacturer's instructions.

Data analysis. Data are means \pm SEM of at least three independent experiments. For PCR, intensities of bands of PCR products were measured using a Lumi-Imager. We calculated the ratio of the intensity integral of target PCR products to that of $\beta$-actin. For statistical analyses, the unpaired Student's $t$ test was applied. We considered a $p$ value of less than 0.05 to be statistically significant.

\section{Results}

Effect of MLD-STZ on $\mathrm{H}_{2} \mathrm{O}_{2}$ generation. Significantly increased $\mathrm{H}_{2} \mathrm{O}_{2}$ levels $(p<0.05)$ were obtained on day 3 after the final STZ injection in islets of male mice only, compared with the results of solvent-injected controls (Fig. 1). In islets of female mice, $\mathrm{H}_{2} \mathrm{O}_{2}$ was not generated by MLD-STZ. The $\mathrm{H}_{2} \mathrm{O}_{2}$ levels were similar in islets of solvent-injected control groups of both sexes. Thus, MLD-STZ stimulates $\mathrm{H}_{2} \mathrm{O}_{2}$ generation in islets of diabetes-susceptible male mice only.

Effect of MLD-STZ on GPX activity. As shown in Figure 2, in islets of male mice, the GPX activity was significantly reduced by MLD-STZ on day 1 after the final injection compared with the solvent-injected controls $(p<0.001)$. On day 3 after the final injection, the activity was comparable to that of the control islets. However, in islets of female mice, MLD-STZ stimulated GPX activities significantly on day 3 after the final STZ-injection $(p<0.01)$. Furthermore, on day 1 after the final STZ-injection, the GPX activity was significantly higher in female mice than in male mice $(p<0.001)$, which had reduced GPX activity. Thus, resistance against MLD-STZ-induced $\mathrm{H}_{2} \mathrm{O}_{2}$ generation and diabetes is associated with the up-regulation of GPX activity, which detoxifies $\mathrm{H}_{2} \mathrm{O}_{2}$ to $\mathrm{H}_{2} \mathrm{O}$ and $\mathrm{O}_{2}$. 


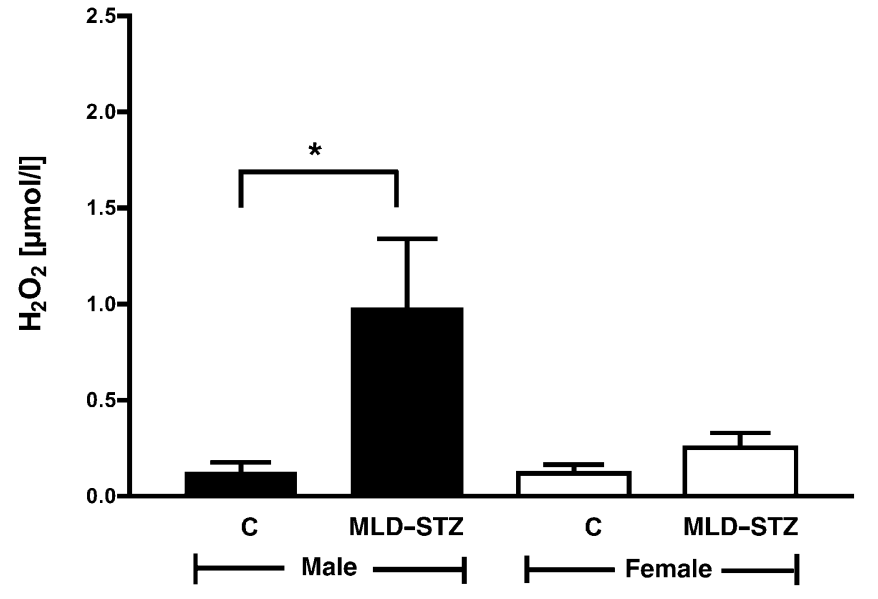

Fig. 1. Ex vivo levels of hydrogen peroxide $\left(\mathrm{H}_{2} \mathrm{O}_{2}\right)$ generation in groups of 150 pancreatic islets isolated from $\mathrm{C} 57 \mathrm{BL} / 6$ mice of both sexes that had been injected with multiple low doses of streptozotocin (MLD-STZ), or with the solvent as controls (C). Islets were isolated on day 3 (3) after the final injection. MLDSTZ stimulated significant $\mathrm{H}_{2} \mathrm{O}_{2}$ generation in islets of male mice only. Data are means \pm SEM of three independent experiments. $* p<0.05$

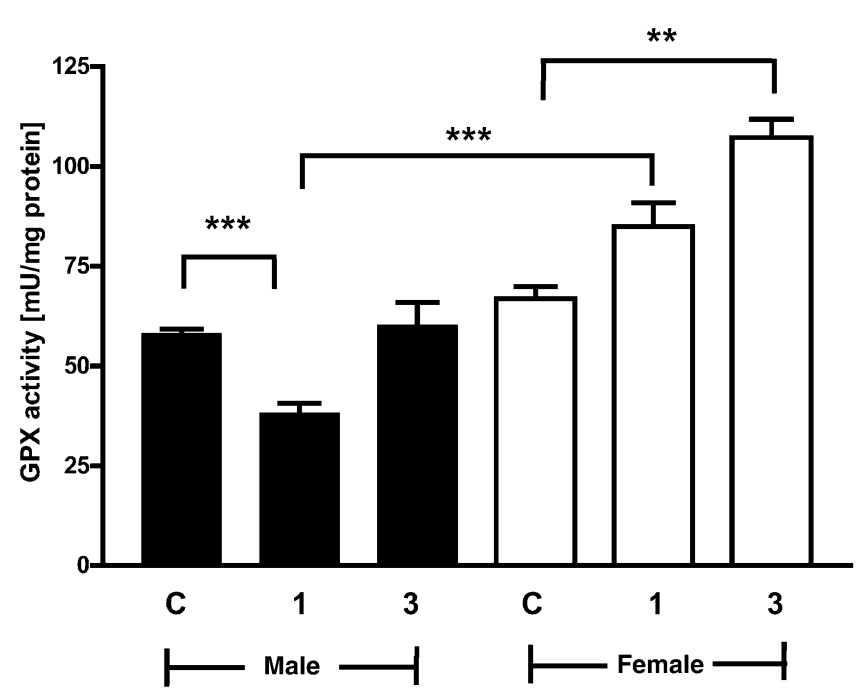

Fig. 2. Ex vivo levels of glutathione peroxidase (GPX) activity in groups of 300 pancreatic islets isolated from C57BL/6 mice of both sexes that had been injected with multiple low doses of streptozotocin, or with the solvent as controls (C). Islets were isolated on day 1 (1) and day 3 (3) after the final injection. Data are means \pm SEM of three independent experiments. The GPX activity was significantly reduced on day 1 in islets of male mice, but significantly increased on day 3 in those of female mice. $* * p<0.01 ; * * * p<0.001$

Effect of MLD-STZ on cellular antioxidative enzymes. The resistance of female mice to MLD-STZ diabetes may rely upon the up-regulation of several antioxidative enzymes. As illustrated in Figure 3, in islets of MLD-STZ-injected male mice, the levels of mRNA expression of $\mathrm{Cu} / \mathrm{Zn}$ and $\mathrm{Mn} \mathrm{SOD}$, catalase, GPX1 and GPX4 did not significantly change on day 1 and day 3 after the final injection compared with solventinjected controls. In contrast, in islets of female mice, MLD-STZ significantly stimulated up-regulation of all five enzymes. MLD-STZ did not affect the levels of these five enzymes in liver specimens (shown for Mn SOD as an example in Fig. 4).

Effect of STZ exposure on $\mathrm{H}_{2} \mathrm{O}_{2}$ generation. Incubation of islets of male donor mice with different concentrations of STZ resulted in dose-dependent $\mathrm{H}_{2} \mathrm{O}_{2}$ generation compared with solvent-incubated control cultures (Fig. 5). Significant $\mathrm{H}_{2} \mathrm{O}_{2}$ generation $(p<0.01)$ was already measured after incubation with $1 \mathrm{mmol} / \mathrm{l} \mathrm{STZ}$; the highest level was obtained with $6 \mathrm{mmol} / \mathrm{l} \mathrm{STZ}\left(7.31 \pm 1.41 \mu \mathrm{mol} / 1 \mathrm{H}_{2} \mathrm{O}_{2}\right)$. Incubation with $10 \mathrm{mmol} / \mathrm{l} \mathrm{STZ}$ did not stimulate significant $\mathrm{H}_{2} \mathrm{O}_{2}$ generation. In contrast, in islets of female mice, significant $\mathrm{H}_{2} \mathrm{O}_{2}$ generation $(p<0.05)$ developed after incubation with $6 \mathrm{mmol} / \mathrm{l} \mathrm{STZ}$ only, yet this $\mathrm{H}_{2} \mathrm{O}_{2}$ level remained significantly below the levels in islets of male mice exposed to 3 or $6 \mathrm{mmol} / \mathrm{l} \mathrm{STZ}$. Thus, STZ stimulated $\mathrm{H}_{2} \mathrm{O}_{2}$ generation in islets of male mice most effectively, and probably required biochemical chain reactions, which were inhibited by the toxic effects of $10 \mathrm{mmol} / \mathrm{l} \mathrm{STZ}$. The specificity of $\mathrm{H}_{2} \mathrm{O}_{2}$ generation was assessed by adding catalase to the supernatant of islet cultures incubated with $6 \mathrm{mmol} / \mathrm{l}$ STZ, which gave the highest $\mathrm{H}_{2} \mathrm{O}_{2}$ level. Catalase completely inhibited $\mathrm{H}_{2} \mathrm{O}_{2}$ generation, presumably through enzymatic inactivation.

Incubation of islets with the two moieties of STZ, methylnitrosourea and D-glucose, did not stimulate $\mathrm{H}_{2} \mathrm{O}_{2}$ generation (Fig. 6a, b). Clearly, transportation of STZ into beta cell compartments by GLUT2 is required for $\mathrm{H}_{2} \mathrm{O}_{2}$ generation. A significant $\mathrm{H}_{2} \mathrm{O}_{2}$ generation $(p<0.05)$ was only obtained after incubation with $10 \mathrm{mmol} / \mathrm{l}$ alloxan (Fig. 6c), which, although markedly lower, did not differ significantly compared with the highest level induced with STZ $(6 \mathrm{mmol} / \mathrm{l})$. Note that $10 \mathrm{mmol} / \mathrm{l}$ of both STZ and alloxan are highly toxic and result in immediate beta cell destruction. The differences in the control cultures are probably due to variabilities inherent to complex methods and multifactorial systems.

Fig. 3. Ex vivo RT-PCR determination of $\mathrm{Cu} / \mathrm{Zn}$ superoxide dismutase (SOD) (a), Mn SOD (b), catalase (c), glutathione peroxidase (GPX) 1 (d) and GPX4 (e) in pancreatic islets of C57BL/6 mice of both sexes that had been injected with multiple low doses of streptozotocin (MLD-STZ), or with the solvent as controls (C). Islets were isolated on day 1 (1) and day 3 (3) after the final injection. Shown are the RT-PCR products and means \pm SEM of the ratio of the target gene to $\beta$-actin mRNA from four independent experiments. The mRNA expression of all five enzymes was not affected by MLD-STZtreated male mice, but was significantly up-regulated in female mice. $* p<0.05$ vs controls; $* * p<0.01$ vs controls; $* * * p<0.001$ vs controls; $\mathrm{M}$, marker 

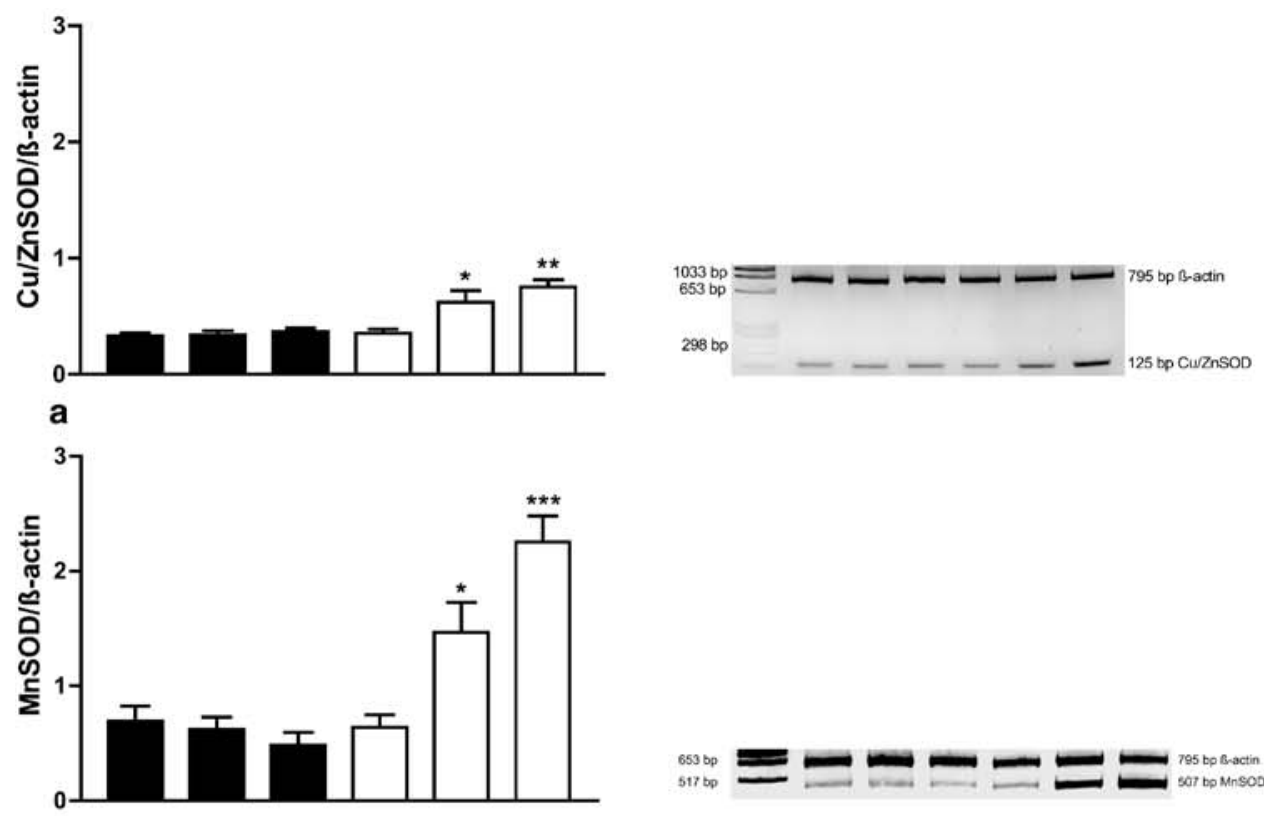

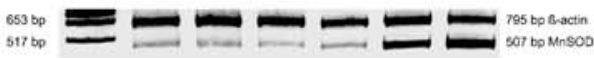

b

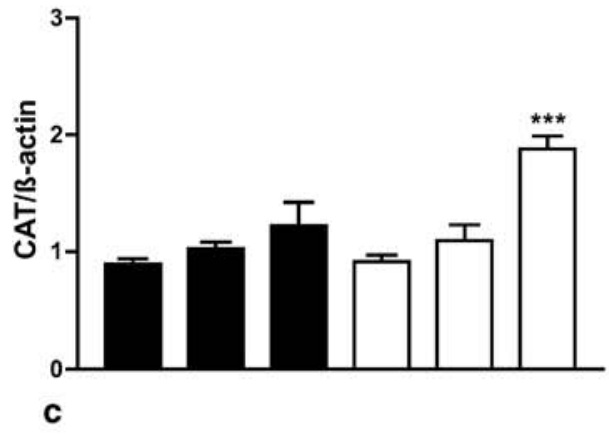

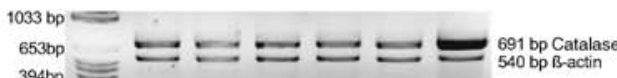
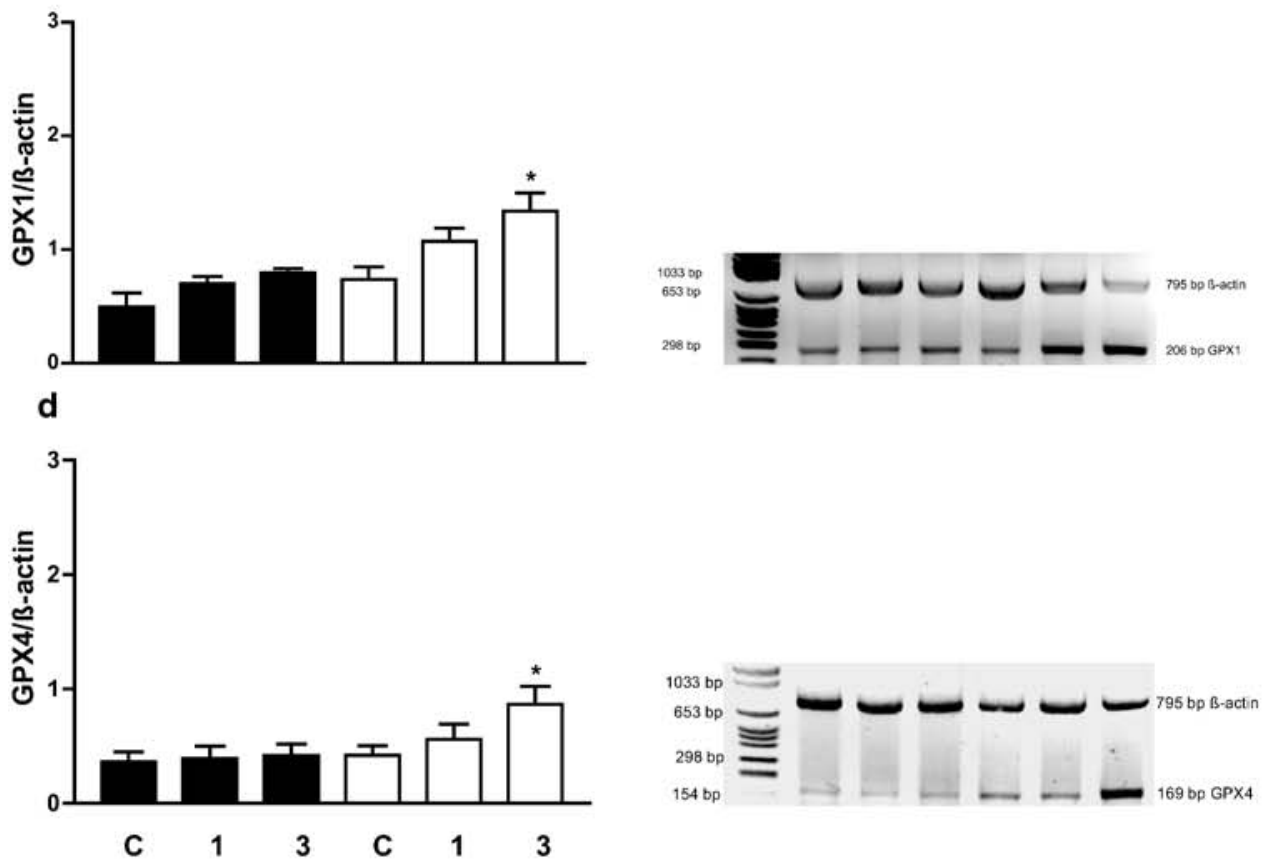

e $\longmapsto$ Male $-1 \longmapsto F e m a l e-1$

Fig. 3. Legend see page 679 


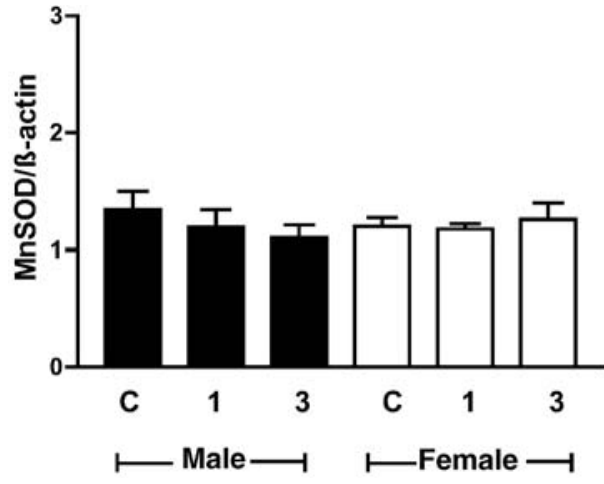

Fig. 4. Ex vivo RT-PCR determination of Mn superoxide dismutase (SOD) liver specimens of C57BL/6 mice of both sexes that had been injected with multiple low doses of streptozotocin (MLD-STZ), or with the solvent as controls (C). Tissue samples were isolated on day 1 (1) and day 3 (3) after the final injection. The mRNA expression of Mn SOD was not affected by MLD-STZ. Shown are the RT-PCR products and means \pm SEM of the ratio of the target gene to $\beta$-actin mRNA from four independent experiments. M, marker

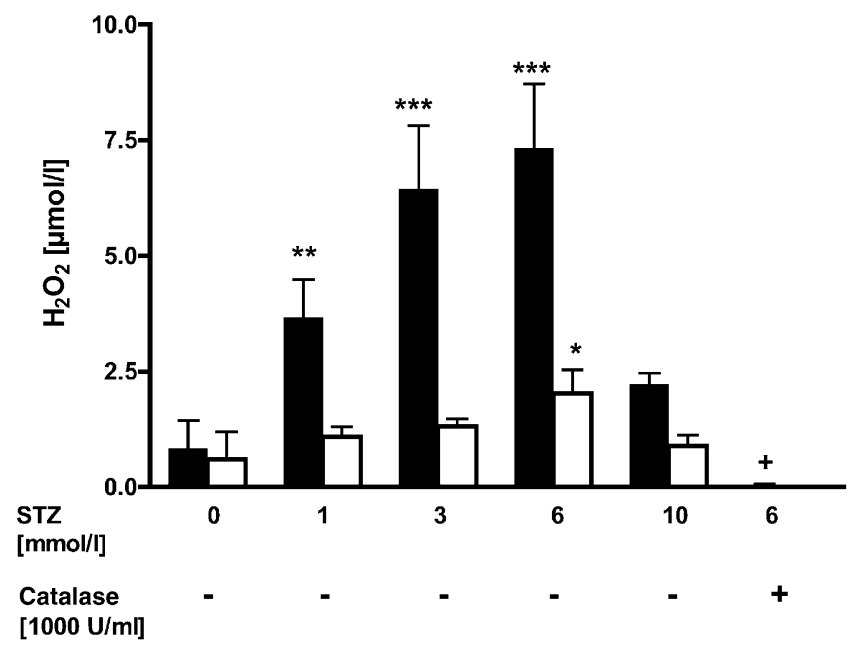

Fig. 5. In vitro hydrogen peroxide $\left(\mathrm{H}_{2} \mathrm{O}_{2}\right)$ levels in supernatants of pancreatic islets isolated from $\mathrm{C} 57 \mathrm{BL} / 6$ mice of both sexes. Groups of 150 islets were incubated with streptozotocin (STZ) at the concentrations indicated, or with the solvent of STZ (0) at $37{ }^{\circ} \mathrm{C}$ for $30 \mathrm{~min}$. Thereafter, catalase was added to supernatants of islet cultures that had been incubated with $6 \mathrm{mmol} / \mathrm{l} \mathrm{STZ}$. Data are means \pm SEM of three independent experiments with duplicate or triplicate cultures. STZ stimulated $\mathrm{H}_{2} \mathrm{O}_{2}$ generation dose-dependently and significantly in islets of male (black) but not female (white) mice. Supplementation with catalase completely inactivated $\mathrm{H}_{2} \mathrm{O}_{2}$ generated by $6 \mathrm{mmol} / 1 \mathrm{STZ}$. $* p<0.05$ vs controls; $* * p<0.01$ vs controls; $* * * p<0.001$ vs controls; $+p<0.05$ vs cultures with $6 \mathrm{mmol} / \mathrm{l}$ STZ

Effect of STZ exposure on GPX activity. Islets of both sexes were incubated with $6 \mathrm{mmol} / \mathrm{l} \mathrm{STZ}$ or with the solvent as controls. STZ significantly reduced the GPX activity in islets of male mice $(p<0.01)$; the levels decreased from $29.54 \pm 5.9$ to $11.44 \pm 1.9 \mathrm{mU} / \mathrm{mg}$ protein. In contrast, in islets of female mice, STZ

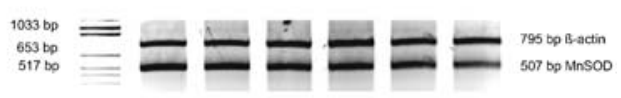

significantly increased the GPX activity from $22.94 \pm 1.52$ to $50.93 \pm 9.05 \mathrm{mU} / \mathrm{mg}$ protein $(p<0.001$; Fig. 7).

Effect of exposure to $\mathrm{STZ}$ and $\mathrm{H}_{2} \mathrm{O}_{2}$ on IRI release. As expected, solvent-incubated islets of male mice responded upon D-glucose challenge with a significantly increased $(p<0.05)$ mean stimulation index (ratio of D-glucose-stimulated IRI to basal IRI) of $10.7 \pm 1.1$ (Fig. 8a) and 5.2 \pm 1.7 (Fig. 8b). Incubation with STZ (Fig. 8a) or $\mathrm{H}_{2} \mathrm{O}_{2}$ (Fig. 8b) at the concentrations indicated resulted in higher basal IRI release compared with solvent-incubated control cultures. Challenge with D-glucose did not stimulate significant changes. Similar results were obtained in islets of female mice (data not shown).

\section{Discussion}

The present data are the first to demonstrate that MLD-STZ diabetes is associated with local generation of $\mathrm{H}_{2} \mathrm{O}_{2}$ in pancreatic islets, which is probably due to insufficient levels of antioxidative enzymes. MLDSTZ stimulated $\mathrm{H}_{2} \mathrm{O}_{2}$ generation in islets of diabetessusceptible male C57BL/6 mice, and did not change levels of mRNA expression of the antioxidants $\mathrm{Cu} / \mathrm{Zn}$ and Mn SOD, catalase and the GPX isoforms 1 and 4. Furthermore, a transient reduction of GPX activity resulted from MLD-STZ injections. Completely reversed MLD-STZ effects were induced in islets of diabetes-resistant female mice. MLD-STZ did not stimulate $\mathrm{H}_{2} \mathrm{O}_{2}$ generation, but it increased mRNA in all five antioxidative enzymes as well as increasing GPX activity. The local MLD-STZ effects described in islets are presumably organ specific, as MLD-STZ failed to affect the mRNA expression in liver specimens of both sexes. Thus, our data emphasise the presumed impact of cytoprotective enzymes in beta cell defence mechanisms against ROS. They also support studies demonstrating resistance to diabetes in bioengineered mice that overexpress antioxidative enzymes targeted at beta cells $[6,7,8]$. Moreover, our ex vivo results are consistent with several in vitro findings indicating that insulin-producing cells transfected with ROS-inactivating enzymes combat dam- 

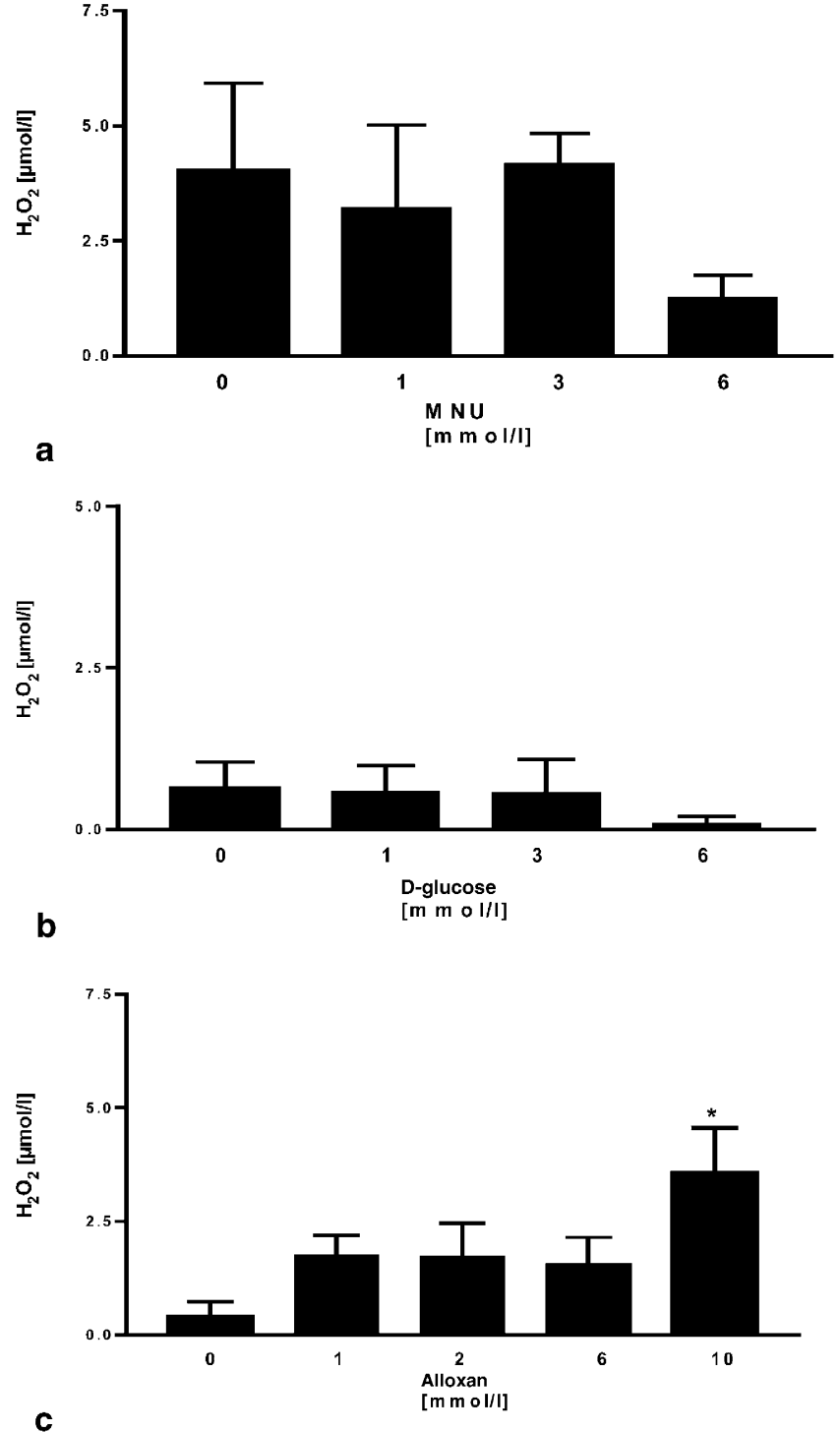

Fig. 6. In vitro hydrogen peroxide $\left(\mathrm{H}_{2} \mathrm{O}_{2}\right)$ levels in supernatants of islets isolated from male C57BL/6 mice. Groups of 150 islets were incubated $\left(37^{\circ} \mathrm{C}, 30 \mathrm{~min}\right)$ with either methylnitrosourea (MNU) (a), D-glucose (b) or alloxan (c) at the concentrations indicated. Islets incubated with the solvent of the reagents $(0)$ served as controls. Data are means \pm SEM of three independent experiments. Neither methylnitrosourea nor D-glucose stimulated $\mathrm{H}_{2} \mathrm{O}_{2}$ generation, but $10 \mathrm{mmol} / \mathrm{l}$ alloxan did. $* p<0.05$ vs controls

Fig. 8. In vitro basal $(\Delta)$ and D-glucose-stimulated $(\mathbf{O})$ immunoreactive insulin (IRI) release in pancreatic islets isolated from C57BL/6 male mice. Cultures of 10 islets had been incubated $\left(37^{\circ} \mathrm{C}, 30 \mathrm{~min}\right)$ with streptozotocin (STZ) (a) or hydrogen peroxide $\left(\mathrm{H}_{2} \mathrm{O}_{2}\right)($ b) at the concentrations indicated. Islets incubated with the solvent of the reagents served as controls (0). Results were obtained in at least three independent experiments with duplicate or triplicate cultures. Mean values are indicated by bars. Significant stimulation of IRI release by D-glucose occurred only in solvent-incubated islets with a mean stimulation index of $10.7 \pm 1.1$. No significant IRI release was measured in the solvent-incubated islet cultures and supernatants of STZ-incubated or $\mathrm{H}_{2} \mathrm{O}_{2}$-incubated islets. $* p<0.05$ vs basal IRI release

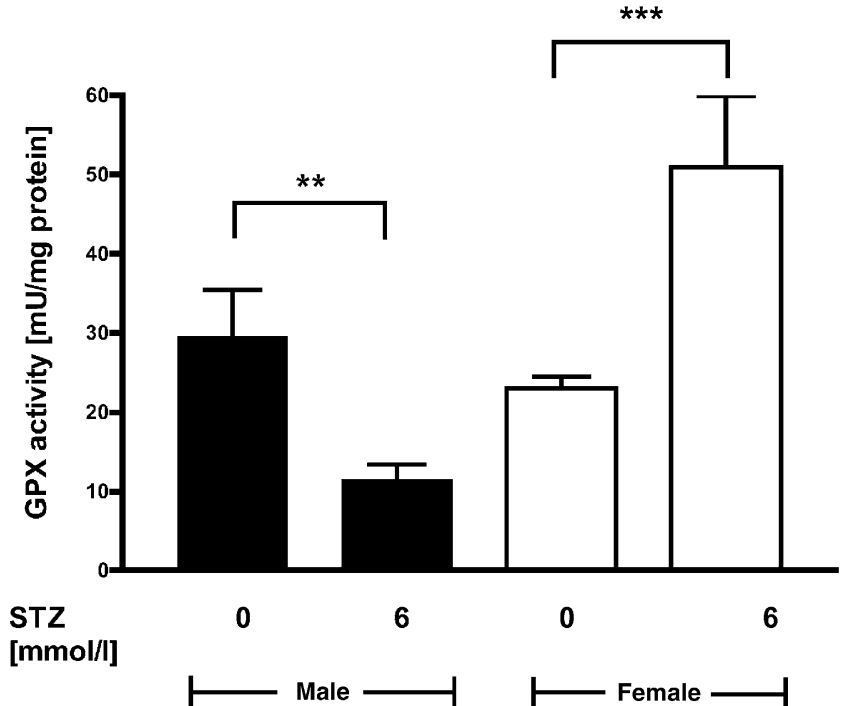

Fig. 7. In vitro glutathione peroxidase (GPX) activity in groups of 300 pancreatic islets isolated from C57BL/6 mice of both sexes that had been incubated $\left(37^{\circ} \mathrm{C}, 30 \mathrm{~min}\right)$ with $6 \mathrm{mmol} / \mathrm{l}$ streptozotocin (STZ), or with the solvent (0) as controls. Data are means \pm SEM of four independent experiments. The GPX activity was significantly reduced in islets of male mice, but significantly increased in those of female mice. $* * p<0.01 ; * * * p<0.001$
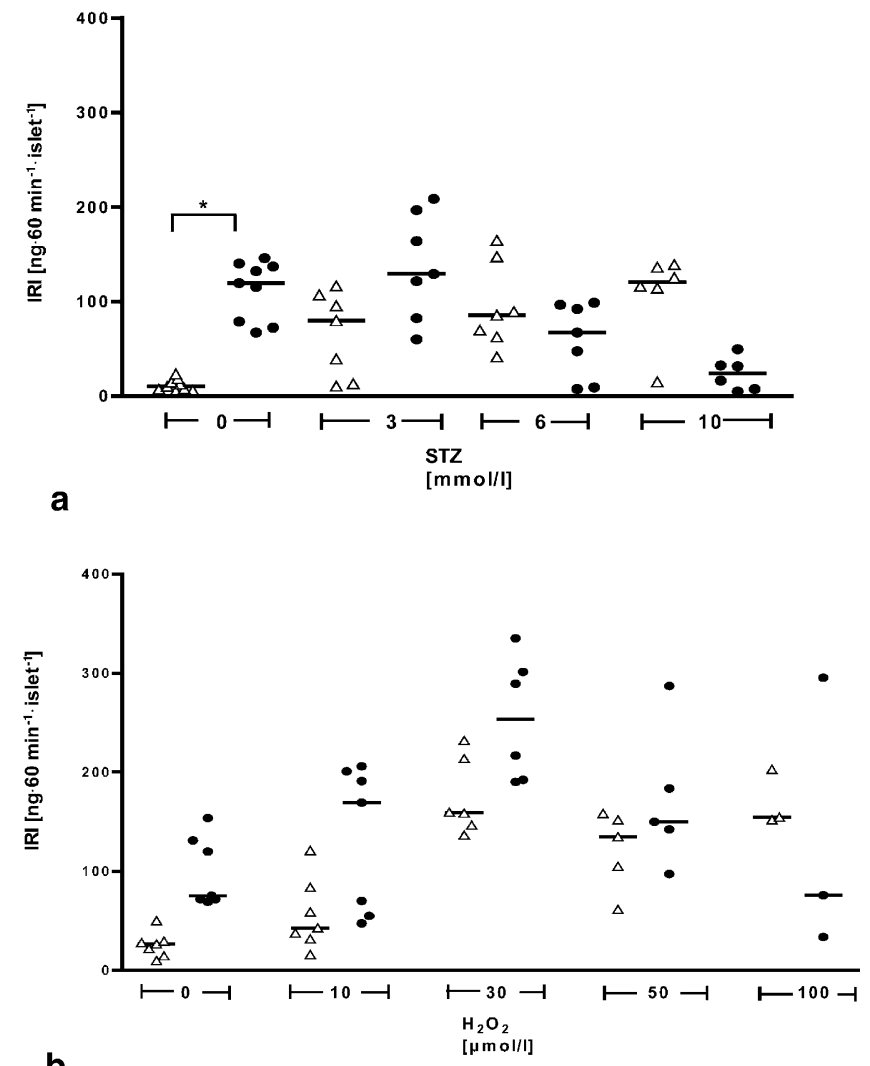
age induced by oxidative stress $[9,10,11]$. However, the effect on local ROS generation has not been measured in islets of transgenic mice or transfected insulin-producing cells overexpressing antioxidants.

Our data are the first to relate MLD-STZ-induced $\mathrm{H}_{2} \mathrm{O}_{2}$ generation to diabetes susceptibility. This observation is important because it strengthens assumptions described previously by this laboratory [21]. Briefly, in vitro, STZ stimulates generation of hydroxyl radicals $(\cdot \mathrm{OH})$, the most toxic species of the group of ROS, in isolated islets. In the cascade of ROS generation, $\mathrm{H}_{2} \mathrm{O}_{2}$ is required to promote the formation of $\mathrm{OH}$ in the presence of $\mathrm{Fe}^{++}$, which can catalyse the Fenton reaction to convert $\mathrm{H}_{2} \mathrm{O}_{2}$ into $\mathrm{OH}$ and $\mathrm{H}_{2} \mathrm{O}$. Thus, the sequence of reactions stimulated by STZ in vitro may reflect similar interactions in vivo. In addition, there is indirect evidence for mitochondrially derived ROS formation, as the very marked up-regulation of Mn SOD in islets of MLD-STZ-injected female mice may reflect efficient metabolisation of $\mathrm{O}_{2}{ }^{-\cdot}$ resulting from respiratory chain reactions.

To generate $\mathrm{H}_{2} \mathrm{O}_{2}$, both moieties of STZ are required, since neither methylnitrosourea nor D-glucose alone does so. Thus, specific direction of STZ to the beta cells and transportation into intracellular compartments by the facilitative GLUT2 is essential for the stimulation of the deleterious signal cascade [14, 31]. Presumably, the diabetogenicity of STZ in the MLD-STZ system is determined by ROS generation, as STZ and methylnitrosourea are similar alkylating agents in vitro [19, 32], but methylnitrosourea is not diabetogenic [20]. Moreover, the alkylating potential of STZ in the MLD-STZ system remains to be shown.

Assessing the mRNA expression of $\mathrm{Cu} / \mathrm{Zn}$ and $\mathrm{Mn}$ SOD, catalase, GPX1 and GPX4, Tiedge et al. [12] found expression of $\mathrm{Cu} / \mathrm{Zn}$ and $\mathrm{Mn} \mathrm{SOD}$, as well as of GPX4 but not of GPX1 in isolated rat islets, and expression of $\mathrm{Cu} / \mathrm{Zn}$ and $\mathrm{Mn} \mathrm{SOD}$ and catalase, but not of GPX 1 and GPX4 in RINm5F cells. In contrast, we found gene expression of all five antioxidative enzymes in murine islets ex vivo. Therefore, the activity of GPX1 in rat islets described by Tiedge et al. [12] is supported by our data showing its gene expression. Whether the described differences are species dependent and modulate susceptibility to STZ remains to be tested. Concerning the translation of RNA levels into activities, we assume that the reduced and increased RNA levels of the present study reflect diminished and augmented protein activities respectively. This is similar to our findings regarding GPX activity, as described above, and to recent reports demonstrating that RNA levels determine enzyme activities, as observed for CuZn and Mn SOD, catalase and GPX, and are usually translated into activities [11, 12].

Whether the slight increase of catalase and GPX1 in male mice is biologically efficacious remains to be resolved.
The generation of ROS by MLD-STZ is probably involved in the development of diabetes. Although STZ is not an ROS generator as such, it may interact with islet cell components in a way that triggers the cascade of ROS formation. In vitro, STZ stimulated $\mathrm{O}_{2}^{-\cdot}$ generation in the presence of the xanthine oxidase system [32] and in isolated submitochondrial particles [21]. This enhanced $\mathrm{O}_{2}^{--}$generation activates the vicious cycle of the complex molecule interactions in the cascade of ROS formation. In islets of male mice, an imbalance develops in favour of ROS, which may damage beta cell structures. Female mice, on the other hand, can cope with this oxidative stress through antioxidative enzyme responses, preventing damage to their beta cells. It is assumed that the inversed MLDSTZ-induced responses of oxidants and antioxidants are regulated by the sex-determining hormones. The experimental design to test this assumption would be to study the effect of acute pre-treatment of male and female mice with oestradiol and testosterone respectively, and to perform long-term sexual changes by castration and ovarectomy. Such experiments would complement those demonstrating sex-dependent susceptibility to MLD-STZ diabetes $[34,35]$. The results could further elucidate the impact of ROS in MLDSTZ diabetogenesis.

Once available, ROS may activate the transcription factor NF- $\mathrm{BB}$ in islets [16], which is involved in gene activation of pro-inflammatory cytokines [36], and it may sustain local inflammatory reactions. In the group of ROS, $\mathrm{H}_{2} \mathrm{O}_{2}$ was shown to be an activator of NF- $\kappa \mathrm{B}$ [37]. Thus, depending on the type of reaction, cells can respond to ROS with antioxidative, protective activities, or can use them as second messengers in signal transduction $[17,38]$.

Finally, the unexpected in vitro data are discussed, which indicate similar responses in basal and D-glucose-stimulated IRI release in islets of both sexes. We propose that the STZ- and $\mathrm{H}_{2} \mathrm{O}_{2}$-stimulated IRI results are caused by passive leakage due to immediate effects, damaging other beta cell structures in addition to GLUT2. Therefore, the signalling pathway for responding to a challenge is disturbed. Apparently, due to multiple effects on beta cell structure, exposure of islets to extracellular $\mathrm{H}_{2} \mathrm{O}_{2}$ or STZ does not reflect effects of intracellular STZ-stimulated $\mathrm{H}_{2} \mathrm{O}_{2}$ generation and antioxidative responses, which are assumed to be relevant for beta cell function in vivo. Thus, applying only in vitro IRI responses of isolated islets may not be sufficient to understand in vivo mechanisms.

In summary, this study shows that MLD-STZ stimulates $\mathrm{H}_{2} \mathrm{O}_{2}$ generation in pancreatic islets of diabetessusceptible C57BL/6 male mice, but does not affect the mRNA expression of the antioxidative enzymes $\mathrm{Cu} / \mathrm{Zn}$ and Mn SOD, catalase, GPX1 and GPX4. However, MLD-STZ does transiently reduce GPX activity. In contrast, in female mice, MLD-STZ up- 
regulated all five antioxidative systems, which may confer resistance to $\mathrm{H}_{2} \mathrm{O}_{2}$ generation and diabetes. The results suggest that antioxidative strategies may be warranted for beta cell transplants and for prevention and intervention in patients with high risk of Type 1 diabetes.

Acknowledgements. This study was supported by the German Research Foundation SFB 503 "Molecular and Cellular Mediators of Exogeneous Noxae" and project B5, and by the Ministry for Health in Bonn, Germany.

\section{References}

1. Tisch R, McDevitt H (1996) Insulin-dependent diabetes mellitus. Cell 85:291-297

2. Rabinovitch A (1998) An update on cytokines in the pathogenesis of insulin-dependent diabetes mellitus. Diabetes Metab Rev 14:129-151

3. Oberley LW (1988) Free radicals and diabetes. Free Radic Biol Med 5:113-124

4. Eizirik DL, Pavlovic D (1997) Is there a role for nitric oxide in beta-cell dysfunction and damage in IDDM? Diabetes Metab Rev 13:293-307

5. Kubisch HM, Wang J, Bray TM, Phillips JP (1997) Targeted overexpression of $\mathrm{Cu} / \mathrm{Zn}$ superoxide dismutase protects pancreatic beta-cells against oxidative stress. Diabetes 46:1563-1566

6. Xu B, Moritz JT, Epstein PN (1999) Overexpression of catalase provides partial protection to transgenic mouse beta cells. Free Radic Biol Med 27:830-837

7. Hotta M, Tashiro F, Ikegami H et al. (1998) Pancreatic beta cell-specific expression of thioredoxin, an antioxidative and antiapoptotic protein, prevents autoimmune and streptozotocin-induced diabetes. J Exp Med 188:14451451

8. Chen H, Carlson EC, Pellet L, Moritz JT, Epstein PN (2001) Overexpression of metallothionein in pancreatic beta-cells reduces streptozotocin-induced DNA damage and diabetes. Diabetes 50:2040-2046

9. Tiedge M, Lortz S, Munday R, Lenzen S (1999) Protection against the co-operative toxicity of nitric oxide and oxygen free radicals by overexpression of antioxidant enzymes in bioengineered insulin-producing RINm5F cells. Diabetologia 42:849-855

10. Lortz S, Tiedge M, Nachtwey T, Karlsen AE, Nerup J, Lenzen S (2000) Protection of insulin-producing RINm5F cells against cytokine-mediated toxicity through overexpression of antioxidant enzymes. Diabetes 49:1123-1130

11. Azevedo-Martins AK, Lortz S, Lenzen S, Curi R, Eizirik DL, Tiedge M (2003) Improvement of the mitochondrial antioxidant defense status prevents cytokine-induced nuclear factor-kappaB activation in insulin-producing cells. Diabetes 52:93-101

12. Tiedge M, Lortz S, Drinkgern J, Lenzen S (1997) Relation between antioxidant enzyme gene expression and antioxidative defense status of insulin-producing cells. Diabetes 46:1733-1742

13. Klinkhammer C, Popowa P, Gleichmann H (1988) Specific immunity to streptozocin. Cellular requirements for induction of lymphoproliferation. Diabetes 37:74-80

14. Wang Z, Gleichmann H (1998) GLUT2 in pancreatic islets: crucial target molecule in diabetes induced with multiple low doses of streptozotocin in mice. Diabetes 47:50-56
15. Müller A, Schott-Ohly P, Dohle C, Gleichmann H (2002) Differential regulation of Th1-type and Th2-type cytokine profiles in pancreatic islets of C57BL/6 and BALB/c mice by multiple low doses of streptozotocin. Immunobiology 205:35-50

16. Lgssiar A, Hassan M, Schott-Ohly P, Friesen N, Nicoletti F, Gleichmann H (2003) Recombinant human interleukin-11 inhibits NFKB and AP-1 activation in pancreatic islets and prevents diabetes induced with multiple low doses of streptozotocin. Diabetes 52 [Suppl 1]:A66

17. Schulze-Osthoff K, Los M, Baeuerle PA (1995) Redox signalling by transcription factors NF-kappa B and AP-1 in lymphocytes. Biochem Pharmacol 50:735-741

18. Chen FE, Ghosh G (1999) Regulation of DNA binding by Rel/NF-kappaB transcription factors: structural views. Oncogene 18:6845-6852

19. LeDoux SP, Woodley SE, Patton NJ, Wilson GL (1986) Mechanisms of nitrosourea-induced beta-cell damage. Alterations in DNA. Diabetes 35:866-872

20. Elsner M, Guldbakke B, Tiedge M, Munday R, Lenzen S (2000) Relative importance of transport and alkylation for pancreatic beta-cell toxicity of streptozotocin. Diabetologia 43:1528-1533

21. Gille L, Schott-Ohly P, Friesen N et al. (2002) Generation of hydroxyl radicals mediated by streptozotocin in pancreatic islets of mice in vitro. Pharmacol Toxicol 90:317326

22. Like AA, Rossini AA (1976) Streptozotocin-induced pancreatic insulitis: new model of diabetes mellitus. Science 193:415-417

23. Wang Z, Dohle C, Friemann J, Green BS, Gleichmann H (1993) Prevention of high- and low-dose STZ-induced diabetes with D-glucose and 5-thio-D-glucose. Diabetes 42:420-428

24. Zimny S, Gogolin F, Abel J, Gleichmann H (1993) Metallothionein in isolated pancreatic islets of mice: induction by zinc and streptozotocin, a naturally occurring diabetogen. Arch Toxicol 67:61-65

25. Rossini AA, Like AA, Chick WL, Appel MC, Cahill GF Jr (1977) Studies of streptozotocin-induced insulitis and diabetes. Proc Natl Acad Sci USA 74:2485-2489

26. Wang Z, Gleichmann H (1995) Glucose transporter 2 expression: prevention of streptozotocin-induced reduction in beta-cells with 5-thio-D-glucose. Exp Clin Endocrinol Diabetes 103 [Suppl 2]:83-97

27. Root RK, Metcalf J, Oshino N, Chance B (1975) $\mathrm{H}_{2} \mathrm{O}_{2}$ release from human granulocytes during phagocytosis. I. Documentation, quantitation, and some regulating factors. J Clin Invest 55:945-955

28. Clifford DP, Repine JE (1984) Measurement of oxidizing radicals by polymorphonuclear leukocytes. Methods Enzymol 105:393-398

29. Paglia DE, Valentine WN (1967) Studies on the quantitative and qualitative characterization of erythrocyte glutathione peroxidase. J Lab Clin Med 70:158-169

30. Chomczynski P, Sacchi N (1987) Single-step method of RNA isolation by acid guanidinium thiocyanate-phenolchloroform extraction. Anal Biochem 162:156-159

31. Schnedl WJ, Ferber S, Johnson JH, Newgard CB (1994) STZ transport and cytotoxicity. Specific enhancement in GLUT2-expressing cells. Diabetes 43:1326-1333

32. Wilson GL, Hartig PC, Patton NJ, LeDoux SP (1988) Mechanisms of nitrosourea-induced beta-cell damage. Activation of poly (ADP-ribose) synthetase and cellular distribution. Diabetes 37:213-216

33. Nukatsuka M, Sakurai H, Yoshimura Y, Nishida M, Kawada $\mathrm{J}$ (1988) Enhancement by streptozotocin of $\mathrm{O}_{2}^{-}$radical gen- 
eration by the xanthine oxidase system of pancreatic betacells. FEBS Lett 239:295-298

34. Rao A (1994) NF-ATp: a transcription factor required for the co-ordinate induction of several cytokine genes. Immunol Today 15:274-281

35. Rossini AA, William RM, Appel MC, Like AA (1978)

Sex differences in the multiple-dose streptozotocin model of diabetes. Endocrinology 103:1518-1520
36. Maclaren NK, Neufeld M, McLaughlin JV, Taylor G (1980) Androgen sensitization of streptozotocin-induced diabetes in mice. Diabetes 29:716-766

37. Schreck R, Rieber P, Baeuerle PA (1991) Reactive oxygen intermediates as apparently widely used messengers in the activation of the NF-kappa B transcription factor and HIV-1. EMBO J 10:2247-2258

38. Ho E, Bray TM (1999) Antioxidants, NFkB activation, and diabetogenesis. Proc Soc Exp Biol Med 222:205-213 